\title{
Neotropical Monogenoidea
}

2. The Anacanthorinae Price, 1967, with the proposal of

four new species of Anacanthorus Mizelle \& Price, 1965, from Amazonian fishes

\author{
D. C. Kritsky (") \\ V. E. Thatcher ("*) \\ R. J. Kayton (*t*)
}

\begin{abstract}
Four species of Monogenoiden (Dactylogyridav) are reported from the gills of freshwater fishes from Amazonas, Brasil, as follows: Anacanthorus spatulatus sp. n. from Colossoma bidens (Spix) and C. macropomum (Cuvier), and A, elegans $\mathrm{sp}, \mathrm{n}$. ., A. spiralocirrus melanopterus (Cope). Additionally, the status of the subfamily Anacanthorinae is discussed, and the diagnosis of Anacanthorus is emended.
\end{abstract}

The Anacanthorinae (Dactylogyridae), consisting of Anacanthorus Mizelle \& Price, 1965. and Anacanthoroides Kritsky \& Thatcher, 1974, is presently restricted to the Neotropical Region. Mizelle \& Price (1965) erected Anacanthorus for their new species, $A$. anacanthorus, A. brazilensis, and A. neotropicalis, collected from the gills of the red-breasted piranha, Serrasalmus nattereri Kner, from the Amazon River. Mizeile \& Kritsky (1969) described $A$. brevis from Brycon melanopterus (Cope) from the Rio Xeruiné, Amazonas. Anacanthorus colombianus and $A$. cuticulovaginus were described from Salminus affinis from the Rio Jamundi (Kritsky and Thatcher, 1974), and Anacanthoroides was proposed for A. mizellei collected from Prochilodus reticulatus Steindachner from the Rio Palo and Rio Frio, Colombia (Kritsky \& Thatcher, 1976). In the present paper, four new species, Anacanthorus elegans, A. kruidenieri, A. spathulatus, and A. spiralocirrus, are reported from fishes of Amazonia.

The monogenoideans reported herein were collected by the second author from freshwater fishes taken near Manaus, Amazonas, Brasil during 1978. Fish gills were placed in finger bowls, and covered with a 1:4000 formalin solution. After one-half hour, the gills were agitated in this liquid and removed from the bowl. The material remaining was sedimented by hand, in the same container, and the helminths were located with the aid of a stereoscopic dissecting microscope. They were immediately fixed and stored in AFA. Some were mounted unstained in Gray and and Wess' medium for study of sclerotized structures. Other specimens stained with Mayer's acid carmalum or Gomori's trichrome were used to determine internal features. Measurements, all in micrometers, were made according to the procedures of Mizelle \& Klucka (1953). Illustrations were prepared with the aid of a camera lucida or microprojector. Type specimens were deposited in the collections of the Instituto Nacional de Pesquisas da Amazônia (INPA), the Museu de Zoologia da Universidade de São Paulo (MUSP), the University of Nebraska State Museum (UNSM) and the U.S. National Museum (USNM) .

\section{Anacanthorus Mizelle \& Price, 1965}

Emended generic diagnosis: Dactylogyridae: Anacanthorinae: Body divisible into cephalic region, trunk, peduncle, haptor. Tegument thin, smooth. Cephalic lobes, head organs, cephalic glands present. Four eyes. Pharynx muscular, glandular; esophagus present; intestinal crura two, confluent posterior to testis, without diverticula. Gonads tandem, intercecal; testis postovarian. Vagina, seminal receptacle usually absent. Uterus

\footnotetext{
( ${ }^{\bullet}$ ) - Department of Allied Health Professions, Idaho State University, Pocatello, Idaho, U.S.A.

( $\cdots$ ) - Instituto Nacional de Pesquisas da Amazônia, Manaus.

(***) - Department of Biology, Idaho State University, Pocatello, Idaho, U.S.A.
} 
well developed, with terminal metraterm consisting of lightly sclerotized internal wall. Common genital pore midventral. Vitellaria well developed. Haptor with 10 (5 pairs, 1 reduced) ventral hooks and 8 (4 pairs, 1 reduced) dorsal hooks. Anchors, bars absent. Parasites of freshwater fishes.

Type species: Anacanthorus anacanthorus Mizelle and Price, 1965, from Serrasalmus nattereri Kner, Amazon River.

\section{Anacanthorus elegans sp. $\mathrm{n}$.}

(Figs, 1-3)

\author{
Host: Brycon melanopterus (Cope) \\ "Matrinchã". \\ Location: Gills . \\ Locality: Janauacá Lake, near Manaus, \\ Amazonas, Brasil. \\ Types: INPA (holotype \& paratypes); \\ MUSP (paratype); USNM (para- \\ type); UNSM (paratype).
}

Description (based on 12 specimens):

Body fusiform, 908 (704-1,061) long; greatest width $120(92-184)$ in trunk. Cephalic lobes variable, usually two terminal, two lateral; head organs poorly developed; cephalic glands inconspicuous, lying near postero-lateral margin of pharynx. Eyes equidistant; members of posterior pair larger; accessory granules absent. Mouth subterminal; pharynx subovate, 50 (39-70) wide, with long axis directed dorsoventrally; esophagus moderately long; intestinal crura simple. Peduncle broad; haptor 73 (51-122) long, 77 (51-133) wide, bilobed, posterior border concave. Large hooks similar; each 37 (34-41) long, with proximal bulb, sickle-shaped point, small thumb; filamentous hook loop ( $\mathrm{FH}$ loop) 0.3 shank length. Small hooks 14 (12-15) long. splinter shaped, lacking FH loop. Gonads occasionally somewhat overlapping; testis subovate, 175 (146-188) long, 85 (56-148) wide; vas deferens looping left intestinal crus; seminal vesicle a slight dilation of vas deferens. Cirrus" a simple tube, reflexive, 189 (148-224) long (from reflex to distal tip), with flared distal end. Accessory piece 50 (42-56) long, comprising a membranous sheath around cirrus with fimbriated lamella. Ovary pyriform, 80 (76-84) long, 62 (28-78) wide; ootype inconspicuous; uterus delicate; vagina, seminal receptacle absent. Vitellaria random in trunk except absent in regions of other reproductive organs.

\section{Remarks :}

The nearest relative of this species is apparently Anacanthorus brevis Mizelle and Kritsky, 1969, as indicated by the comparative morphology of the hooks and cirrus base. Anacanthorus elegans, sp. $\mathrm{n}$., differs from this species by possessing an accessory piece (absent in A. brevis), and a reflexive cirrus tube (straight in A. brevis) and by being more than twice as large as A. brevis. The specific name is from the Latin (elegans = elegant).

Bychowsky (1957) reports that self fertilization is common in all families of Monogenoidea. Several specimens in the type series show indirect evidence that $A$. elegans also may utilize this process in some cases. We frequently observed the distal reflexed portion of the cirrus inserted into the uterus in individual specimens.

\section{Anacanthorus spatulatus $\mathrm{sp} . \mathrm{n}$.} (Figs, 4-6)

Hosts: Colossoma bidens (Spix) "Pirapitinga". Colossoma macropomum (Cuvier) "Tambaquí".

Location: Gills.

Locality: Janauacá Lake, near Manaus, Amazonas, Brasil.

Types: INPA (holotype \& paratypes); MUSP (paratype); USNM (paratype); UNSM (paratype).

\section{Description (based on 20 specimens):}

Body fusiform, 671 (449-877) long: greatest width 137 (102-214) near midlength. Cephalic lobes well developed, two terminal. two lateral; cephalic glands numerous, conspicuous, lying in two bilateral groups posterolateral to pharynx; head organs four, large. Members of posterior pair of eyes larger. 

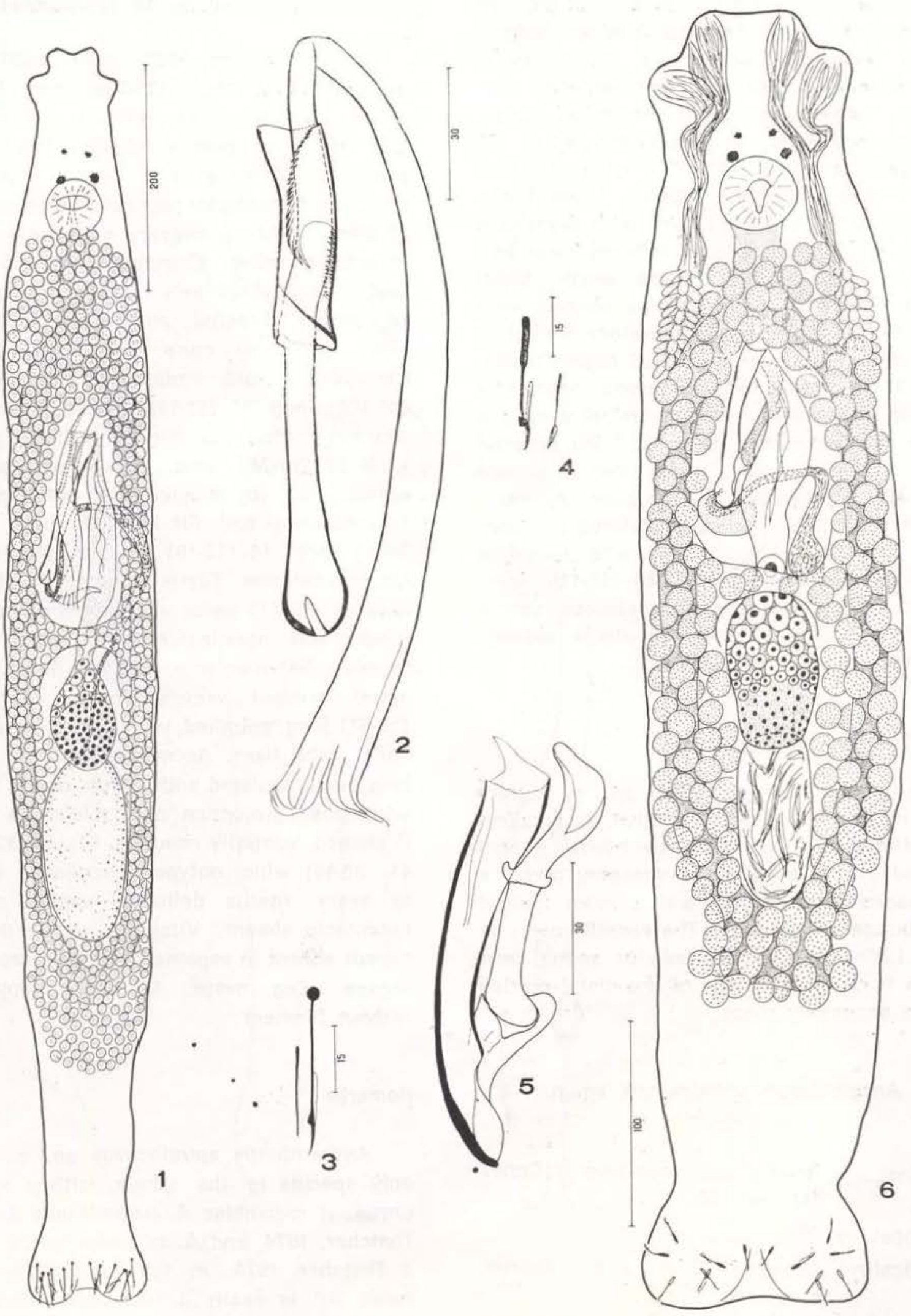

Figures 1-3, Anacanthorus elegans sp. n. 1, Whole mount (composite, ventral). 2, Copulatory complex. 3, Hooks. Figures 4-6, Anacanthorus spathulatus sp. n. 4, Hooks. 5, Copulatory complex. 6, Whole mount (composite, ventral). 
usually farther apart than members of anterinr pair; accessory granules absent. Mouth subterminal; pharynx subovate, 45 (36-59) wide. with long axis directed dorsoventrally: es ${ }^{n}$. phagus moderately long; intestinal crurs simple. Peduncle very broad; haptor 62 (31-133) long, 101 (51-143) wide, bilober. with concave posterior border. Large hooks similar; each 29 (26-39) long, with depressed thumb, sickle-shaped point, inflated basal hali of shank; FH loop 0.4 shank length. Smal! hooks 17 (14-19) long, splinter shaped, witn delicate FH loop. Gonads occasionally slightly overlapping. Testis subovate, 86 (56-109) long. $43 \quad(31-50)$ wide; vas deferens apparently looping left intestinal crus; seminal vesicle a simple dilation of vas deferens, lying sinistral to ootype. Cirrus 89 (73-112) long, a simple tube with terminal spine, large base. Accessory piece 67 (42-78) long, articulated to cirrus base, with rod-like proximal and spatulate distal ends. Ovary pyriform, 80 (56-118) long. 50 (28-84) wide; ootype inconspicuous; uterus delicate; vagina seminal receptacle absent. Vitellaria co-extensive with gut.

\section{Remarks :}

Anacanthorus spatulatus sp. $\mathrm{n}$. differs from its nearest apparent relative, $A$. brazilensis Mizelle \& Price. 1965, by having a well defined cirrus, a spatulate acessory piece, a depressed hook thumb, and a more limited distribution of vitellaria. The specific name is from Latin (spatula = blade or spoon) and refers to the morphology of the distal portion of the accessory piece.

\section{Anacanthorus spiralocirrus $\mathrm{sp} . \mathrm{n}$.}

(Figs, 7-9)

Host: Brycon melanopterus (Cope) "Matrinchã".

Location: Gills.

Locality: Janauacá Lake, near Manaus, Amazonas, Brasil.

Types:- INPA (holotype \& paratypes): MUSP (paratype); USNM (paratype); UNSM (paratype).
Describtion (based on 19 specimens):

Body fusiform, 808 (541-1020) iong:' greatest width 181 (122-255) near level of testis. Cephalic lobes incipient, one terminal, two bilateral; cephalic glands, head organs poorly differentiated. Eyes equidistant; members of posterior pair larger than members of anterior pair; accessory granules scattered in anterior trunk. Pharynx 80 (53-115) wide, ovate, longitudinal axis directed dorsoventrally, mouth directed posteriorly; esophagus short; intestinal crura closely adjacent to reproductive field. Peduncle broad; haptor 66 (41-102) long, 97 (51-163) wide, bilobed, with concave posterior border. Large hooks similar; each 22 (21-24) long, with open point, depressed thumb; shank with proximal bulb. tapered distal end; FH loop 0.8 shank length. Small hooks 14 (12-19) long, splinter shaped; FH lcop delicate. Testis elongate, 154 (98-190) long, 24 (20-31) wide; vas deferens apparently looping left intestina! crus, extending ventral to ovary between proximal and distal ovarian arms: seminal vesicle absent. Cirrus 74 (59-87) long, spiralled, with spined base, 1.5 - 2 coils, distal flare. Accessory piece 38 (36-42) long, nonarticulated with cirrus, sickle shaped, with small projection near midlength. Ovary C shaped, ventrally concave, 97 (64-112) iong. 41 (36-45) wide; ootype immediately anterior to ovary; uterus delicate; vagina, seminal receptacle absent. Vitellaria random in trunk except absent in regions of other reproductive organs. Egg ovate, 143 long, apparently withcut filament.

\section{Remarks :}

Anacanthorus spiralocirrus $\mathrm{sp} . \mathrm{n}$. is the only species in the genus with a spiralled cirrus. It resembles $A$. colombianus Kritsky \& Thatcher, 1974, and A. cuticulovaginus Kritsky \& Thatcher, 1974, in the morphology of the hook, but is easily differentiated from them by the non-articulated cirrus and accessory piece. The specific name indicates the unique morphology of the cirrus. 

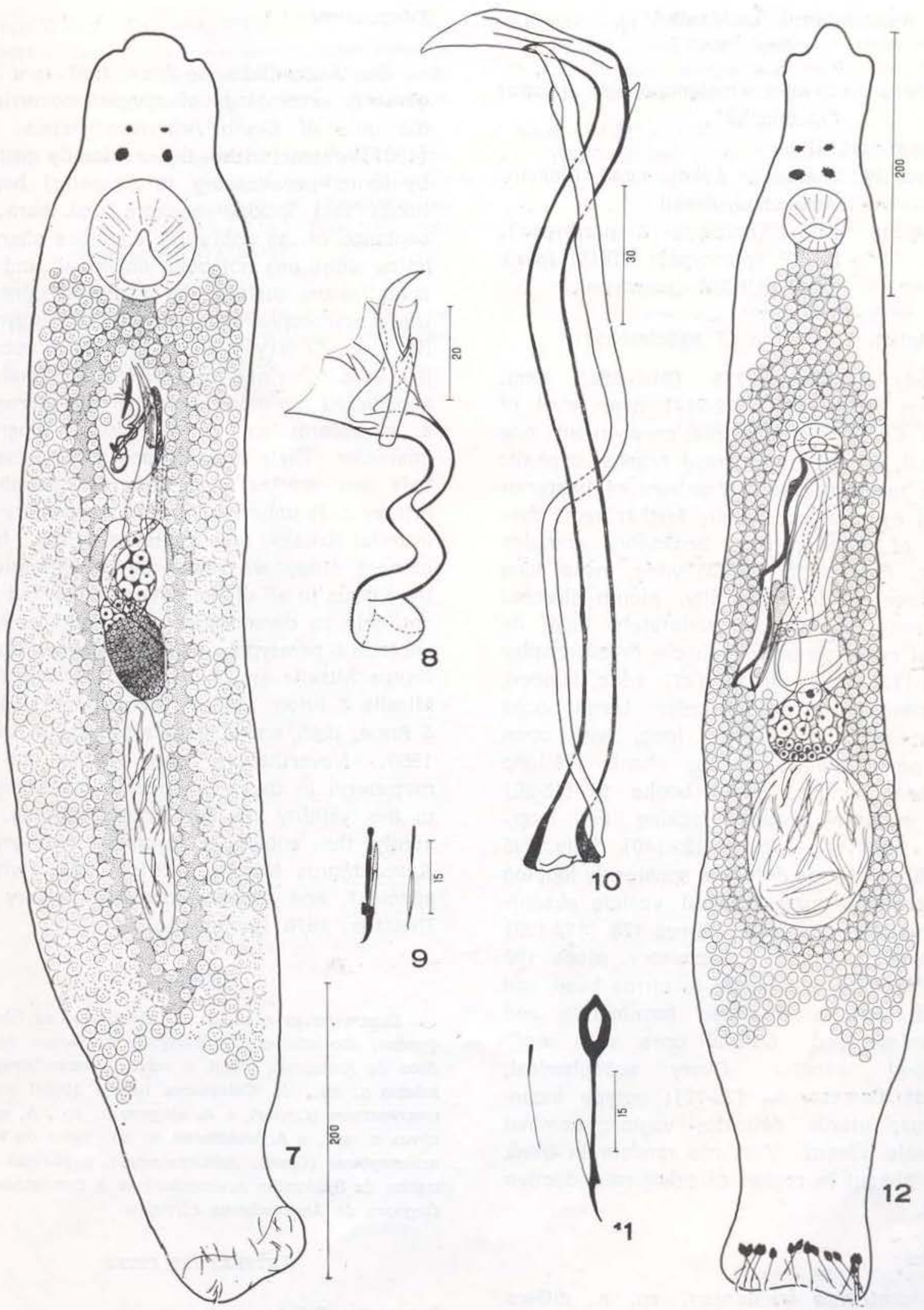

Figures 7-9, Anacanthorus spiralocirrus sp. n. 7, Whole mount (composite, ventral). 8, Copulatory complex. 9, Hooks. Figures 10-12, Anacanthorus kruidenieri sp. n. 10, Copulatory complex. 11. Hooks, 12, Whole mount (composite, ventral). 
Anacanthorus kruidenieri $\mathrm{sp}$. $\mathrm{n}$.

(Figs, 10-12)

\author{
Host: Brycon melanopterus (Cope) \\ "Matrinchã". \\ Location: Gills. \\ Locality: Janauacá Lake, near Manaus, \\ Amazonas, Brasil. \\ Types: INPA (holotype \& paratypes); \\ MUSP (paratype); USNM (para- \\ type); UNSM (paratype).
}

Description (based on 17 specimens):

Body fusiform, 755 (612-959) long; greatest width $157 \quad(122-214)$ near level of testis. Cephalic lobes three, conspicuous, one terminal, two bilateral; head organs, cephalic glands inconspicuous. Members of posterior pair of eyes larger, usually farther apart than those of anterior pair; accessory granules absent. Pharynx 53 (39-73) wide, ovate, long axis directed dorsoventrally, mouth directed posteriorly; esophagus moderately long; intestinal crura simple. Peduncle broad; haptor 67 (41-112) long, 90 (51-133) wide, bilobed, with concave posterior border. Large hooks similar; each 44 (42-46) long, with open point, small thumb, buibous shank; FH loop 0.3 shank length. Small books $18(15-20)$ long, splinter shaped, lacking FH loop. Testis subovate, $125(112-140)$ long, 95 (73-109) wide; vas deferens apparently looping left intestinal crus; seminal vesicle absent; two prostatic reservoirs. Cirrus 176 (162-190) long. scythe shaped. Accessory piece 162 (148-174) long, articulated to cirrus base, rod shaped, with sickle-shape termination and subterminal pad. Genital pore with welldeveloped spincter. Ovary subspherical. greatest diameter 54 (36-70); ootype inconspicuous; uterus delicate; vagina, seminal receptacle absent. Vitellaria random in trunk except absent in region of other reproductive organs.

Remarks :

Anacanthorus kruidenieri, sp. n., differs from all known species in the genus by having a massively enlarged proximal end of the hook. This species is named for Dr. F. J. Kruidenier, University of Illinois, Urbana, USA.

\section{Discussion}

The Anacanthorinae Price, 1967, is a homogeneous assemblage of species occurring on the gills of South American fishes. Price (1967) characterized the subfamily primarily by forms possesssing 18 ( 9 pairs) haptoral hooks and lacking anchors and bars. Acceptance of the subfamily on these characteristics alone has not been universal, and most investigators include the enclosed genera in the Ancyrocephalinae of the Dactylogyridae. Recently, Kritsky \& Thatcher (1976) accepted the Anacanthorinae on a provisional basis and considered the modification of the uterus into a metraterm as an additional diagnostic character. Their observations were based on only two species, Anacanthorus colombianus Kritsky \& Thatcher, 1974, and Anacanthoroides mizellei Kritsky and Thatcher, 1976. In the present study we found the modification of the uterus in all of the new species, but were not able to demonstrate it in highly-cleared, unstained paratypes of Anacanthorus anacanthorus Mizelle and Price, 1965, A. brazilensis Mizelle \& Price, 1965, A. neotropicalis Mizelle \& Price, 1965, and A. brevis Mizelle \& Kritsky, 1969. Nevertheless, the finding of the metraterm in the new species lends support to the validity of the Anacanthorinae. Presently, the subfamily contains two genera: Anacanthorus Mizelle \& Price, 1965 (with 10 species) and Anacanthoroides Kritsky and Thatcher, 1976 (monotypic).

\section{Resumo}

Quatro novas espécies de Monogenoidea (Dactylogyridae) são citadas das brânquias de peixes de água doce de Amazonas, Brasil, a saber: Anacanthorus spatulatus n. sp., de Colossoma bidens (Spix) e de C. macropomum (Cuvier), e A. elegans n. sp., A. spiralocirrus n. sp., e A. kruidenieri n. sp. todas de Brycon melanopterus (Cope). Adicionalmente, a posição sistemática da Subfamília Anacanthorinae é comentada, e a diagnose de Anacanthorus corrigida.

\section{LITERATURE CITED}

BYCHOWSKY, B.E.

1957 - Monogenetic Trematodes, Their Systematics and Phylogeny. Akad. Nauk S.S.S.R. p. 1-509. (translated from Russian by P.C. Oustinoff, AlBS, Washington D.C.J. 
KrTrSKy, D.C. \& ThATCher, V.E.

1974 - Monogenetic trematodes (Monopisthocotylea: Dactylogyridae) from freshwater fishes of Colombia, South America. J. Helminth., 48 : 59-66.

1976 - New monogenetic trematodes from freshwater fishes of western Colombia with the proposal of Anacanthroides gen. n. (Dactylogyridae). Proc. Helm. Soc. Washington, $43: 129-134$.

Mizelle, J.D. \& Klucka, A.R.

1953 - Studies on monogenetic trematodes. XIV. Dactylogyridae from Wisconsin fishes. Am. Midl. Nat., $49: 720-733$.
Mizelle, J.D. \& KritsKy, D.C.

1969 - Studies on monogenetic trematodes. XL. New species from marine and freshwater fishes. Am. Midl. Nat., $82: 417-428$.

Mizelle, J.D. \& Price, C.E.

1965 - Studies on monogenetic trematodes. XXVIII. Gill parasites of the piranha with the proposal of Anacanthorus gen. n. J. Parasit., 51 : 30-36.

Price, C.E.

1967 - Two new subfamilies of monogenetic trematodes. Quart. J. Fla. Acad. Sci., 29 : 199-201.

(Aceito para publicaçāo em 9/04/79) 